\title{
Betaeus truncatus Dana, 1852 (Crustacea: Decapoda: Caridea: Alpheidae) from South Georgia, South Atlantic Ocean - a new sub-Antarctic record of alpheid shrimps
}

\section{Betaeus truncatus Dana, 1852 (Crustacea: Decapoda: Caridea: Alpheidae) из Южной Георгии, Южная Атлантика - новая находка каридных креветок в Субантарктике}

\author{
Ivan N. Marin ${ }^{1}$, Sergey E. Anosov ${ }^{2}$ \\ И.Н. Марин ${ }^{1}$, С.Е. Аносов
}

\begin{abstract}
${ }^{1}$ A.N. Severtzov Institute of Ecology and Evolution of RAS, Leninsky pr. 33, Moscow, 117071 Russia. E-mail: coralliodecapoda@mail.ru (corresponding author)

${ }^{1}$ Институт проблем экологии и эволюции им. А.Н. Северцова РАН (ИПЭЭ РАН), Ленинский просп., 33, Москва, 117071 Россия.

${ }^{2}$ Russian Federal Research Institute of Fishery and Oceanography, Verkh. Krasnoselskaya str., 17, Moscow, 107140 Russia. E-mail: anosov@vniro.ru; anosov@aquarius-s.ru

${ }^{1}$ Всероссийский научно-исследовательский институт рыбного хозяйства и океанографии (ВНИРО), ул.Верхняя Красносельская, 17, Москва, 107140 Россия.
\end{abstract}

KEY WORDS: Decapoda, Caridea, shrimp, Alpheidae, Betaeus, new record, Sub-Antarctic, South Georgia, South Atlantic Ocean.

КЛЮЧЕВЫЕ СЛОВА: Decapoda, Caridea, креветки, Alpheidae, Betaeus, новые находки, Субантарктика, Южная Георгия, Южный Атлантический Океан.

ABSTRACT. The alpheid shrimp Betaeus truncatus Dana, 1852 (Decapoda: Alpheidae) is firstly reported from sub-Antarctic coastal shallow waters of South Georgia, South Atlantic Ocean. The present locality situated about $1500 \mathrm{~km}$ east from the nearest distribution area of the shrimp species, off Falkland Islands.

РЕЗЮМЕ. Креветка-альфеида Betaeus truncatus Dana, 1852 (Decapoda: Alpheidae) впервые отмечена из прибрежных вод Южной Георгии, Субантарктическая часть Атлантического Океана. Отмеченная точка обитания находится в более чем 1500 км от ближайшего ранее указанного местообитания данного вида - Фолклендских островов, что существенной увеличивает ареал обитания вида.

\section{Introduction}

The alpheid shrimp genus Betaeus Dana, 1952 (Crustacea: Decapoda: Alpheidae) presently includes 16 valid species [e.g. De Grave, Fransen, 2011]. Two of them, Betaeus truncatus Dana, 1852 and B. lilianae Boschi, 1966, are known from the most southern part of South American continent, so called Subantarctic Magellan region. The third alpheid species recorded from the area is Alpheus puapeba Christoffersen, 1979 [Boschi, 1966, 1979; Christoffersen, 1979; Spivak, 1997]. Betaeus truncatus is a common littoral species living underneath stones, between seaweed and bank of mussels at the depth of $0-50 \mathrm{~m}$ along mainland coast and coastal fjords of southern Argentina, southern Chile, Patagonia and area of Falkland Islands [Boschi et al., 1992; Spivak, 1997; Thatje, Bacardit, 2001]. Planktonic larvae of the species distribute in the area between $37^{\circ} 35^{\prime} \mathrm{S} 53^{\circ} 40^{\prime} \mathrm{W}$ and $55^{\circ} 15^{\prime} \mathrm{S} 68^{\circ} 15^{\prime} \mathrm{W}$ [Thatje, Bacardit, 2001] and probably east to South Georgia and South Sandwich Islands.

South Georgia and the South Sandwich Islands situated about $1900 \mathrm{~km}$ east from the nearest continental coast of South America and Tierra del Fuego, Patagonia and about $1500 \mathrm{~km}$ south-east from Falkland Islands. Littoral fauna of this archipelago is poorly studied but still poorly studied. The paper presents the record of the species of the genus Betaeus Dana, 1852, identified as B. truncatus Dana, 1852, collected at littoral shallow waters of South Georgia representing the first record of the family Alpheidae from this locality.

\section{Material and methods}

The single ovigerous female was collected in South Atlantic Ocean, South Georgia, Shag Rocks, 53332’ S $42^{\circ} 022^{\prime} \mathrm{W}$. Exact collecting methods are unknown, not indicated in the label. The material is deposited in the collection of Directorate of Natural Resources Fisheries Department (DNRFD), Stanley, Falkland Islands. Total body length (tl., $\mathrm{mm}$ ) and postorbital carapace length (pcl. $\mathrm{mm}$ ) are used as standard measurements. Only primary synonyms are given. 


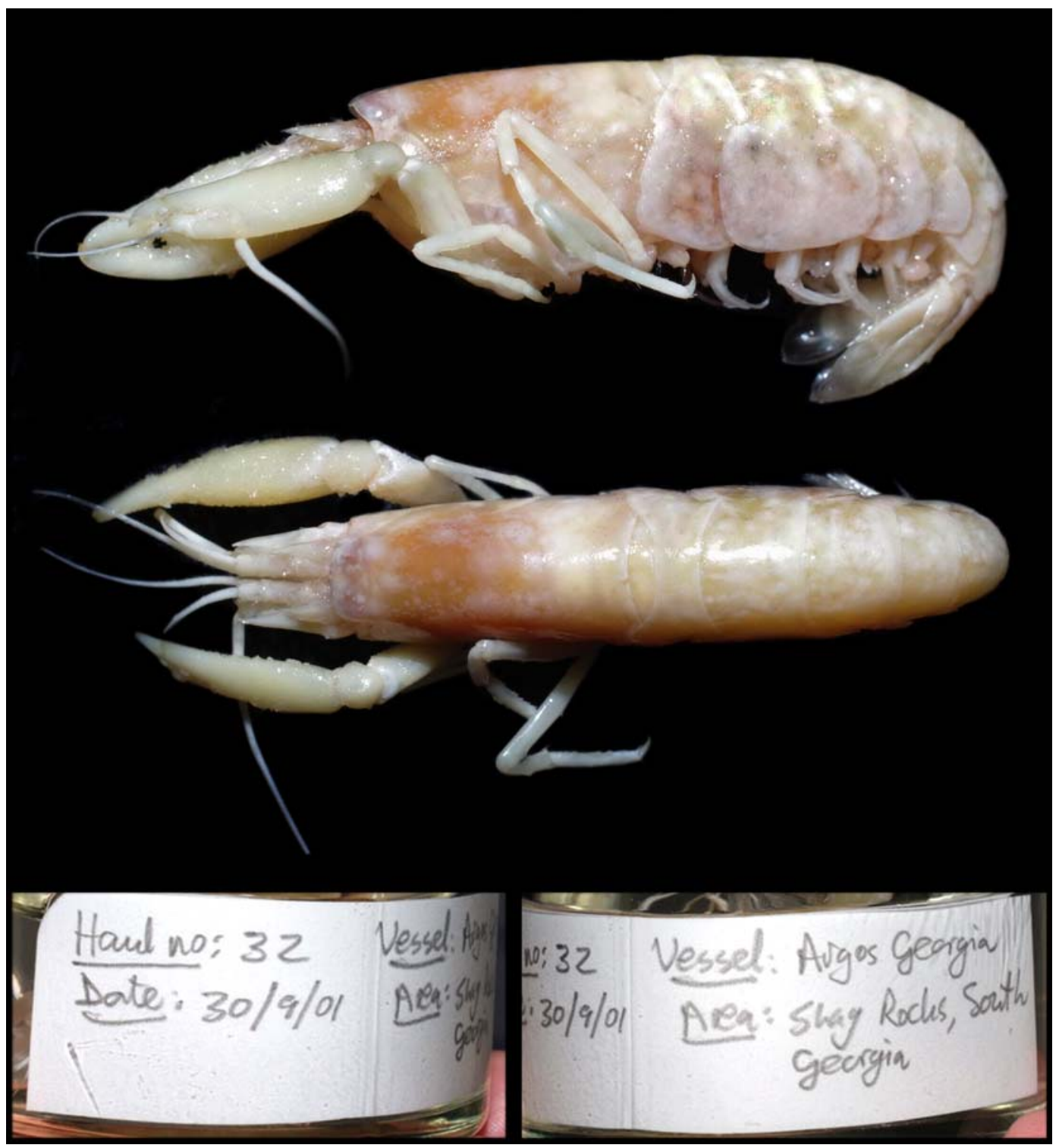

Fig. 1. Betaeus truncatus Dana, 1852, fixed ovigerous female, DNRFD-ZDC4, Shag Rocks, South Georgia, lateral, dorsal views and the label (taken from tube) below.

Pис. 1. Betaeus truncatus Dana, 1852, скалы Шаг, Южная Георгия, DNRFD-ZDC4, вид сбоку и сверху, а также этикетка из пробирки

\section{Taxonomy}

Order DECAPODA Latreille, 1802

Family ALPHEIDAE Rafinesque, 1815

Genus Betaeus Dana, 1852

\section{Betaeus truncatus Dana, 1852}

\section{Fig. 1.}

Betceus truncatus Dana, 1852a: 23 [type locality: in mari prope insulam "Hermite"].

Alpheus sinuosus Guérin-Méneville, 1857: 51 [type locality: Callao, Chili].

MATERIAL EXAMINED: 1 Ovigerous female (pcl. $4 \mathrm{~mm}, \mathrm{tl}$ $17 \mathrm{~mm}$ ), South Atlantic Ocean, South Georgia, Shay Rocks, exact coordinates unknown, depth unknown, vessel "Argos Georgia", DNRFD, fixed in $4 \%$ formaldehyde, stored in $70^{\circ}$ ethanol, 30.09.2001, same tube with Campylonotus sp. (Crustacea: Decapoda: Caridea: Campylonotidae).

REMARKS. The single obtained specimen is not eligible for genetic analysis because it was primary fixed in formaldehyde and then transferred to ethanol. Moreover, at present, the specimen is dried. Morphologically it is identical to the description of Betaeus truncatus. At the same time, it is possible that the genetic analysis of freshly collected specimens from South Georgia and South Sandwich Islands (probable area of the occurrence of the species) can show the difference from the mainland population as the distance of the separation between these populations exceeds $1500 \mathrm{~km}$. 
ECOLOGY AND DISTRIBUTION. This is the first record of the species from South Georgia, South Atlantic Ocean. Following the label in the tube, where specimen was preserved, it was found subtidal, under stone at the depth of $0.5 \mathrm{~m}$. Betaeus truncatus is widely distributed in coastal shallow waters of Argentina from $45^{\circ} \mathrm{S}$ to its southern part, fjords of southern Chile, Patagonia and shallow waters of the area of Falkland Islands; 0-50 m [Boschi et al., 1992; Spivak, 1997; Thatje, Bacardit, 2001].

ACKNOWLEDGEMENTS. The authors are very thankful to Dr. Paul Brickle (Directorate of Natural Resources, Fisheries Department, Stanley, Falkland Islands) for sending the specimen for exact identification. The study was partly supported by the Grant of the President of the Russian Federation MK-4481.2014.4 and RFFI \# 12-04-00540-à.

\section{References}

Boschi E.E. 1966. Una nueva especie de crustáceo Decapoda Caridea para las aguas costeras de la provincia de Buenos Aires, Argentina // Physis. Vol.35. No.71. P.83-88.

Boschi E.E. 1979. Geographic distribution of Argentine marine decapod crustaceans // Bulletin of the Biological Society of Washington. Vol.3. P.134-143.
Boschi E.E., Fischbach C.E., Iorío M.I. 1992. Catálogo ilustrado de los crustáceos estomatópodos y decápodos marinos de Argentina // Frente Marítimo. Vol.10A. P.7-94.

Christoffersen M.L. 1979. Campagne de la Calypso au large des côtes Atlantiques de l'Amerique du Sud (1961-1962). part I. Decapod Crustacea: Alpheoida // Annales de 1'Institut Océanographique/ Suppl.55. P.297-377.

Dana J.D. 1852. Conspectus crustaceorum quae in orbis terrarum circumnavigatione, Carol Wilkes e classe reipublicae foederatae duce, lexit e descripsit // Proceedings of the Academy of Natural Sciences of Philadelphia. Vol.6. P.6-28.

De Grave S., Fransen C.H.J.M. 2011. Carideorum catalogus: the recent species of the dendrobranchiate, stenopodidean, procarididean and caridean shrimps (Crustacea: Decapoda) // Zoologische Mededelingen (Leiden). Vol.85. No.9. P.195-589.

Guérin-Méneville F.E. 1857. Animaux articulés à pieds articulés. Crustacés // de la Sagra R. Histoire Physique, Politique et Naturelle de l'Île de Cuba. 87 pp.

Spivak E.D. 1979. Los crustaceos decapodes del Atlantico sudocidental (25-55S): distibucion y ciclos de vida // Investigaciones Marinas, Valparaiso, Chile. Vol.25. P.105-120.

Thatje S., Bacardit R. 2001. Two zoeal stages of Betaeus truncatus (Dana, 1852) (Decapoda: Caridea: Alpheidae) from Argentine coastal waters // Anales del Instituto de la Patagonia, Serie Ciencias Naturales (Chile). Vol.29. P.95-104.

Responsible editor V.A. Spiridonov 